\title{
Persistent carriage of MRSA in pig farmers
}

\author{
BV Cleef ${ }^{1,2^{*}}$, BV Benthem ${ }^{1}$, R Teuwen ${ }^{3}$, J Kluytmans ${ }^{2,3}$ \\ From International Conference on Prevention \& Infection Control (ICPIC 2011) \\ Geneva, Switzerland. 29 June - 2 July 2011
}

\section{Introduction / objectives}

Livestock associated methicillin-resistant Staphylococcus aureus (MRSA) is a known and prevalent pathogen related to livestock farming. Little is known about the dynamics of carriage over time in pig farmers.

\section{Methods}

In this prospective cohort study, pig farmers and their employees from 50 pig farms in The Netherlands were tested for MRSA presence in nose and throat at 5 time points in 8 months. Questionnaires were taken as well. Persistent carriers were defined as persons with $100 \%$ of nasal samples positive for MRSA. Multilevel multivariate regression analysis was performed in SAS. This is a preliminary analysis as the collection of data is still ongoing.

\section{Results}

In total, 130 pig farmers and employees entered the study (101 males, 78\%). Eighty of them (62\%) were MRSA nasal carriers at the start of the study and 49 (38\%) were persistent carriers. Presence of MRSA in throat samples at the start of the study (OR=6.1, 95\% CI 1.6-23.6), giving birth assistance to sows (OR=8.1, 95\% CI 1.9-35.3), and the presence of goats on the farm $(\mathrm{OR}=6.0,95 \% \mathrm{CI} 1.0-35.7)$ were significantly associated with persistent carriage. Amount of working hours per week did improve the model fit, but was not a significant factor $(\mathrm{OR}=1.0, \mathrm{p}=0.18)$.

\section{Conclusion}

The vast majority of persons working with pigs on a daily base is carrier of MRSA and almost $40 \%$ are persistent carriers. Throat carriage and specific tasks or farm characteristics were determinants of persistent carriage.

\section{Disclosure of interest}

None declared.

${ }^{1}$ Centre for Infectious Disease Control Netherlands, RIVM National Institute for Public Health and the Environment, Bilthoven, Netherlands

\section{Author details}

${ }^{1}$ Centre for Infectious Disease Control Netherlands, RIVM National Institute for Public Health and the Environment, Bilthoven, Netherlands. ${ }^{2}$ Department of Medical Microbiology and Infection Prevention, VU University Medical Centre, Amsterdam, Netherlands. ${ }^{3}$ Laboratory for Microbiology and Infection Control, Amphia Hospital, Breda, Netherlands.

Published: 29 June 2011

doi:10.1186/1753-6561-5-S6-P167

Cite this article as: Cleef et al.: Persistent carriage of MRSA in pig farmers. BMC Proceedings 2011 5(Suppl 6):P167.

Submit your next manuscript to BioMed Central and take full advantage of:

- Convenient online submission

- Thorough peer review

- No space constraints or color figure charges

- Immediate publication on acceptance

- Inclusion in PubMed, CAS, Scopus and Google Scholar

- Research which is freely available for redistribution

Submit your manuscript at www.biomedcentral.com/submit

\section{() Biomed Central}

\section{Biomed Central}

